\title{
Influence of pathogen and focus of infection on procalcitonin values in sepsis: are there additional confounding factors?
}

\author{
Patrick M. Honore ${ }^{1 *}$, David De Bels ${ }^{1}$, Rachid Attou ${ }^{1}$, Sebastien Redant ${ }^{1}$, Andrea Gallerani ${ }^{1}$ and Kianoush Kashani ${ }^{2}$ \\ This comment refers to the article available at https://doi.org/10.1186/s13054-018-2050-9.
}

We read the study by Thomas-Rüddel et al. with great interest [1]. Authors showed serum procalcitonin (PCT) concentrations were higher in patients with Gram-negative bacteremia $(26 \mathrm{ng} / \mathrm{ml})$ than in those with Gram-positive bacteremia $(7.1 \mathrm{ng} / \mathrm{ml})$ or candidemia $(P<.0001)$ [1]. They outlined some potential factors that could have impacted the PCT measurement outside to the type, location, and severity of the infection. In addition to their findings, it is essential to highlight that in patients with positive blood culture, septic shock is very common. Acute kidney injury (AKI) is prevalent among patients with sepsis, and a considerable proportion of patients with sepsis-associated AKI (SA-AKI) require renal replacement therapy (RRT) [2]. As PCT has an approximate molecular weight of $14.5 \mathrm{kDa}$ [3], the contemporary continuous RRT membranes are able to remove it (CRRT cutoff is about $35 \mathrm{kDa}$ ) [4]. Also, using newer high adsorptive membranes (HAM) would make PCT removal even more prominent [4]. Accordingly, if in the study by Thomas-Rüddel et al., there was any imbalance between the uses of CRRT between the two groups, it could critically impact the observed results. We, therefore, suggest including the use of CRRT in the prediction model. In addition, the design of future studies to assess the performance of PCT among septic patients who are on CRRT seems to be necessary [5].

\section{Abbreviations}

AKI: Acute kidney injury; CRRT: Continuous renal replacement therapy; HAM: Highly adsorptive membranes; PCT: Procalcitonin; RRT: Renal replacement therapy; SA-AKI: Sepsis-associated AKI

\footnotetext{
* Correspondence: Patrick.Honore@CHU-Brugmann.be

${ }^{1}$ ICU Department, Centre Hospitalier Universitaire Brugmann-Brugmann University Hospital, Place Van Gehuchtenplein,4, 1020 Brussels, Belgium Full list of author information is available at the end of the article
}

Acknowledgements

None.

Authors' contributions

PMH and KK designed the paper. All authors participated in drafting the manuscript. All authors have read and approved the final version.

Funding

None.

Availability of data and materials

Not applicable.

Ethics approval and consent to participate

Not applicable.

Consent for publication

Not applicable.

Competing interests

The authors declare that they have no competing interests.

\section{Author details}

${ }^{1}$ ICU Department, Centre Hospitalier Universitaire Brugmann-Brugmann University Hospital, Place Van Gehuchtenplein,4, 1020 Brussels, Belgium. ${ }^{2}$ Division of Nephrology and Hypertension, Division of Pulmonary and Critical Care Medicine, Mayo Clinic, Rochester, USA.

Received: 16 May 2019 Accepted: 29 May 2019

Published online: 13 June 2019

\section{References}

1. Thomas-Rüddel DO, Poidinger B, Kott M, Weiss M, Reinhart K, Bloos F; MEDUSA study group. Influence of pathogen and focus of infection on procalcitonin values in sepsis patients with bacteremia or candidemia. Crit Care 2018;22(1):128. doi: https://doi.org/10.1186/ s13054-018-2050-9.

2. Peters E, Antonelli M, Wittebole X, Nanchal R, François B, Sakr Y, et al. A worldwide multicentre evaluation of the influence of deterioration or improvement of acute kidney injury on clinical outcome in critically ill patients with and without sepsis at ICU admission: results from The Intensive Care Over Nations audit. Crit Care. 2018;22(1):188. https://doi.org/ 10.1186/s13054-018-2112-z.

3. Level C, Chauveau P, Guisset O, Cazin MC, Lasseur C, Gabinsky C, et al. Mass transfer, clearance, and plasma concentration of procalcitonin during continuous venovenous hemofiltration in

(c) The Author(s). 2019 Open Access This article is distributed under the terms of the Creative Commons Attribution 4.0 International License (http://creativecommons.org/licenses/by/4.0/), which permits unrestricted use, distribution, and reproduction in any medium, provided you give appropriate credit to the original author(s) and the source, provide a link to the Creative Commons license, and indicate if changes were made. The Creative Commons Public Domain Dedication waiver (http://creativecommons.org/publicdomain/zero/1.0/) applies to the data made available in this article, unless otherwise stated. 
patients with septic shock and acute oliguric renal failure. Crit Care. 2003;6:R160-6.

4. Honoré PM, De Bels D, Spapen HD. An update on membranes and cartridges for extracorporeal blood purification in sepsis and septic shock. Curr Opin Crit Care. 2018;24(6):463-8. https://doi.org/10.1097/MCC. 0000000000000542.

5. Honoré PM, Jacobs R, De Waele E, Van Gorp V, Spapen HD. Evaluating sepsis during continuous dialysis: are biomarkers still valid? Blood Purif. 2014;38(2):104-5. https://doi.org/10.1159/000363497 Epub 2014 Oct 17.

\section{Publisher's Note}

Springer Nature remains neutral with regard to jurisdictional claims in published maps and institutional affiliations. 